(c) Group of authors, 2019

UDC 616-007.43:616-089

DOI - https://doi.org/10.14300/mnnc.2019.14112

ISSN - 2073-8137

\title{
SURGICAL TREATMENT OF HIATAL HERNIA BY ROUTINE AND LAPAROSCOPIC METHODS
}

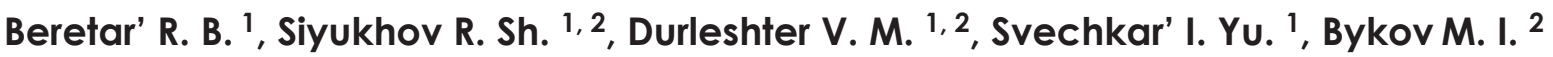 \\ ${ }^{1}$ Region Clinic Hospital № 2, Krasnodar, Russian Federation \\ 2 Kuban State Medical University, Krasnodar, Russian Federation
}

\section{ХИРУРГИЧЕСКОЕ АЕЧЕНИЕ ГРЫЖ ПИЩЕВОАНОГО ОТВЕРСТИЯ АИАФРАГМЫ ТРААИЦИОННЫМ И ААПАРОСКОПИЧЕСКИМ МЕТОААМИ}

\author{
Р. Б. Беретарь 1, Р. Ш. Сиюхов 1, 2, В. М. Аурлештер 1, 2, И. Ю. Свечкарь ', М. И. Быков ${ }^{2}$ \\ ${ }^{1}$ Краевая кАиническая больница № 2, КрасноАар, Российская ФеАерация \\ 2 Кубанский госуАарственный МеАицинский университет, КрасноАар, \\ Российская ФеАерация
}

Anti-reflux surgery was performed in 302 patients with a type 1 hiatal hernia from 2008 to 2016 . The patients were divided into two groups. The first group comprised 241 patients who underwent anti-reflux laparoscopy, and the second group (control group) comprised 61 patients who underwent routine laparotomy. The outcomes were evaluated at 1, 6, 12, and 24 months postoperatively. The results were good to excellent in both groups, but laparoscopy was more advantageous in terms of quality of life as indicated by the Gastrointestinal Quality of Life Index and 36-Item Short Form Survey.

Keywords: hiatal hernia, reflux esophagitis, laparoscopy, anti-reflux surgery

В период с 2008 по 2016 год 302 пациентам с грыжей пищеводного отверстия диафрагмы 1 типа (ГПОД), осложненной рефлюкс-эзофагитом, выполнено антирефлюксное хирургическое лечение по авторской методике. Лапароскопическая антирефлюксная операция по устранению ГПОД (основная группа) выполнена 241 пациенту, из традиционного лапаротомного доступа (контрольная группа) - 61. Результаты хирургического лечения оценивались через 1, 6, 12 и 24 месяца. При достаточно высоком уровне отличных и хороших результатов лечения в обеих группах пациенты с ГПОД, перенесшие лапароскопическую антирефлюксную операцию, имели более лучшие объективные и субъективные (по шкалам GIQLI и SF-36) показатели.

Ключевые слова: грыжа пищеводного отверстия диафрагмы, рефлюкс-эзофагит, лапароскопия, антирефлюксное хирургическое лечение

For citation: Beretar' R. B., Siyukhov R. Sh., Durleshter V. M., Svechkar' I. Yu., Bykov M. I. SURGICAL TREATMENT OF HIATAL HERNIA BY ROUTINE AND LAPAROSCOPIC METHODS. Medical News of North Caucasus. 2019;14(3):466-468. DOI - https://doi.org/10.14300/mnnc.2019.14112

Для цитирования: Беретарь Р. Б., Сиюхов Р. Ш., Дурлештер В. М., Свечкарь И. Ю., Быков М. И. ХИРУРГИЧЕСКОЕ ЛЕЧЕНИЕ ГРЫЖ ПИЩЕВОДНОГО ОТВЕРСТИЯ ДИАФРАГМЫ ТРАДИЦИОННЫМ И ЛАПАРОСКОПИЧЕСКИМ МЕТОДАМИ. Медицинский вестник Северного Кавказа. 2019;14(3):466-468. DOI - https://doi.org/10.14300/mnnc.2019.14112

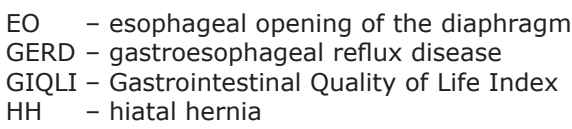

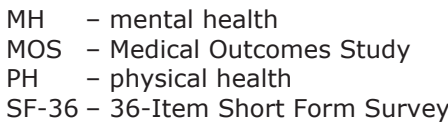

H iatal hernia (HH) is one of the most prevalent conditions encountered in modern gastroenterology. It is also one of the most common benign cardioesophageal pathologies $[1,2]$. Multicenter epidemiological studies have shown a $23.6 \%$ prevalence of gastroesophageal reflux disease (GERD), the main developmental factor of which is an $\mathrm{HH}$. Approximately $25 \%$ of patients with $\mathrm{HH}$ require medical treatment and $15 \%$ require surgical treatment $[2,3]$. The introduction of minimally invasive methods into medical practice has increased the number of treatment options for GERD $[4,5,6]$.
The present study was performed to evaluate the effectiveness and safety of a modified laparoscopic antireflux intervention for $\mathrm{HH}$ at different postoperative time points.

Material and Methods. In accordance with the objectives of this study, 302 patients with type $1 \mathrm{HH}$ complicated by reflux esophagitis were examined. The laparoscopy group comprised 241 (79.8\%) patients who underwent a laparoscopic anti-reflux intervention, and the control group comprised $61(20.2 \%)$ patients who underwent traditional surgery with laparotomy access. Both groups contained more women than men, and the overall age ranged from 20 to 79 years (mean age of men, 
$47.9 \pm 13.0$ years; mean age of women, $53.8 \pm 10.5$ years). There was no statistically significant difference in the proportion of men and women between the two groups ( $p=0.452$ according to the $\chi^{2}$ criterion). Additionally, for both men and women, no statistically significant difference was found in the age distribution between the two groups. All patients included in the study underwent generally accepted clinical, laboratory, and instrumental diagnostic testing used in the diagnosis of GERD.

All patients with indications for surgical treatment underwent videoendoscopic surgical removal of GERD with the formation of areflux cardia and use of a symmetrical circular fundoplication cuff. The essence of the method is that from the laparoscopic approach, the esophageal opening in the diaphragm using the wall of the mobilized gastric fundus. Wherein it by stitching the highest points of the mobilized gastric fundus and adjacent portions of the crura of the diaphragm and the wall of the esophagus with the capture of the phrenoesophageal ligament. Thus, four suture-ligament joints are formed with the patent $2525732 \mathrm{RU}$, which is conducive to preventing reflux [7]. If minimally invasive treatment was impossible, traditional open anti-reflux surgery was performed.

The indications for laparotomic access were severe diseases of the cardiovascular and respiratory systems because of a risk of superimposing carboxyperitoneum, a history of operations involving the esophagus and stomach in combination with a pronounced adhesive process, and large ventral hernias.

The treatment results were analyzed by examination at $1,6,12$, and 24 months postoperatively. In addition, the patients were surveyed using the Gastrointestinal Quality of Life Index (GIQLI) and 36-Item Short Form Survey (SF36) questionnaires.

Data analysis was performed using the standard statistical procedures of the Excel 2010 program and its add-ons «Analysis Package» and «AtteStat», as well as the Russian-language program «Statistica 10» (StatSoft, USA)

Results and Discussion. The duration of the surgical intervention in the laparoscopy group was $126.2 \pm 44.5$ minutes, and that in the control group was $223.2 \pm 42.5$ minutes $(p<0.001)$. During the laparoscopic operations, intraoperative complications requiring conversion to open surgery occurred in eight patients (adhesions in the abdominal cavity and bottom of the stomach, two patients; bleeding from large vessels, four patients; and severe periesophagitis and the inability to identify the esophagogastric transition, two patients).

The postoperative hospital stay was significantly shorter in the laparoscopy group ( $4.5 \pm 1.5$ days) than in the control group $(8.08 \pm 2.1$ days; $p<0.001)$.

There were no fatal outcomes. Complications were diagnosed in $10(4.2 \%)$ patients in the laparoscopy group and $5(8.1 \%)$ patients in the control group. Persistent dysphagia requiring a course of endoscopic bougienage and prolonged conservative treatment occurred in seven $(2.9 \%)$ and five $(8.1 \%)$ patients, respectively. In all cases, a satisfactory result was obtained without signs of gastroesophageal reflux. Cuff migration was detected in 19 patients, 7 of whom also had a clinical picture consistent with recurrence of GERD and reflux esophagitis. We did not regard cuff migration without loss of areflux function as disease relapse. A postoperative $\mathrm{HH}$ was found in one $(0.4 \%)$ patient in the laparoscopy group and six $(9.8 \%)$ patients in the control group. Relapse of GERD and clinical manifestations in the form of reflux esophagitis were detected in five $(1.7 \%)$ patients in the laparoscopy group and in two (3.3\%) patients in the control group.

The proportions of patients with various postoperative complications in the later stages after surgery were comparable between the two groups. Specifically, no significant differences were found in the proportions of patients with persistent dysphagia, cuff migration, or relapse of reflux esophagitis at different postoperative time points according to Fisher's exact criterion and the Yeats-adjusted chi-square criterion ( $p>0.05)$.

Quality of life was assessed using the GIQLI and Medical Outcomes Study (MOS) SF-36 (Fig. 1). A comparison of the average values of the GIQLI indicator between patients in the laparoscopy and control groups showed significant differences only at the 1- and 6-month postoperative time points $(p<0.05)$. However, the difference in the GIQLI indicator between the groups was no longer significant at 12 and 24 months postoperatively.

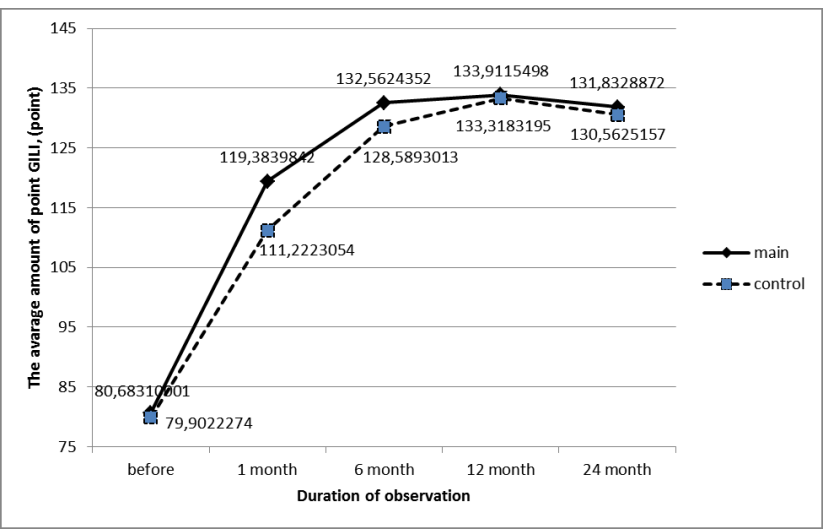

Fig. 1. Dynamics of the average values of the GIQLI indicator in the laparoscopy and control groups ( ${ }^{*}$ statistically significant difference from the indicator values in the control group)

Quality of life was assessed using the MOS SF-36 questionnaire to determine the most effective treatment method. Starting from the preoperative period, the physical indicator of quality of life according to the physical health dimension of the SF-36 for patients in the laparoscopy group constantly increased as the postoperative observation period progressed. The largest increase in the value of the indicator occurred at 1 and 6 months postoperatively. Thereafter, the increase within this group was insignificant, as was the difference in the value compared with the control group $(p<0.05)$ (Fig. 2$)$.

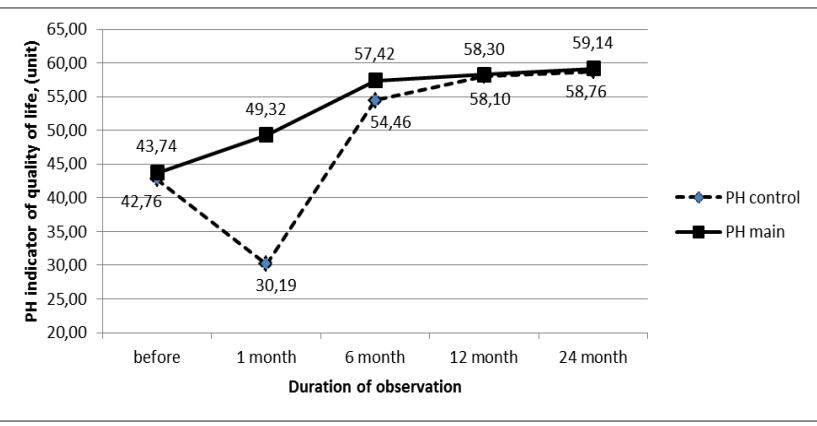

Fig. 2. Dynamics of the values of the $\mathrm{PH}$ indicator in the laparoscopy and control groups

( ${ }^{\#}$ statistically significant difference from the values of the $\mathrm{PH}$ indicator in the control group)

The mental indicator of the quality of life according to the mental health dimension of the SF-36 before surgery was significantly greater for patients in the laparoscopy group than control group $(p<0.05)$ (Fig. 3). After one month postoperatively, however, the values were almost the same. After six months, the indicator was more significant in the laparoscopy group than control group 
$(p<0.05)$. At 12 and 24 months, the indicator values were almost identical $(p>0.05)$.

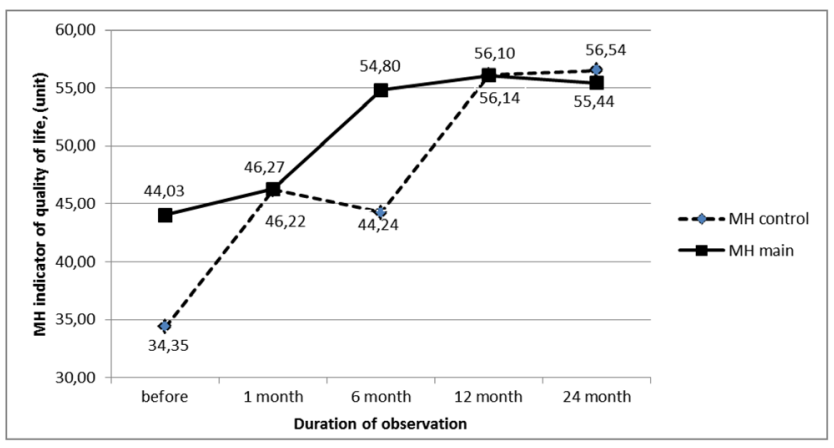

Fig. 3. Dynamics of the values of $\mathrm{MH}$ in the laparoscopy and control groups ( ${ }^{*}$ statistically significant difference from the values of $\mathrm{MH}$ in the control group)
Conclusions. Anti-reflux surgical treatment leads to a statistically significant improvement in patients' quality of life, both those who undergo laparoscopic operations and those who undergo open surgery.

The proposed method of endovascular surgical treatment of GERD has a lower percentage of total postoperative complications than the traditional method as well as a shorter operative time, postoperative observation period, and general hospital stay.

In a comparative analysis of quality of life using the SF-36 (a general questionnaire) and the GIQLI (a gastrointestinalindex), the outcomes ofvideoendoscopic surgical treatment of GERD are superior to those of the traditional laparotomic method in terms of the rate of recovery of physical activity with equal anti-reflux efficacy, making laparoscopic surgery the operation of choice in the treatment of GERD complicated by reflux esophagitis.

\section{Disclosures:}

The authors declare no conflict of interest.

\section{Acknowledgment:}

We thank Angela Morben, DVM, ELS, from Edanz Group (www.edanzediting.com/ac), for editing a draft of this manuscript.

\section{References}

1. Fuchs K. H., Babic B., Breithaupt W., Dallemagne B. Fingerhut A. [et al.] EAES recommendations for the management of gastroesophageal reflux disease. Surgical Endoscopy. 2014;28:1753-1773. https://doi.org/10.1007/s00464-014-3431-z

2. Lazebnik L. B., Masharova A. A., Bordin D. S., Vasiliev Yu. V., Tkachenko E. I. [et al.] Results of a multicenter trial «Epidemiology of Gastroesophageal Reflux Disease in Russia» (MEGRE). Therapeutic archive. 2011;83(1):5-50.

3. Schieman C., Grondin S. C. Paraesophageal Hernia: Clinical Presentation, Evaluation, and Management Controversies. Thoracic Surgery Clinics. 2009;19(4):473-484. https://doi.org/10.1016/j.thorsurg.2009.08.006

4. Antonakis F., Köckerling F., Kallinowski F. Functional Results after Repair of Large Hiatal Hernia by Use of a Biologic Mesh. Frontiers in Surgery. 2016;3:16. https://doi.org/10.3389/fsurg.2016.00016
5. Köckerling F., Trommer Y., Zarras K., Adolf D., Kraft B. [et al.] What are the differences in the outcome of laparoscopic axial (I) versus paraesophageal (II-IV) hiatal hernia repair? Surgical Endoscopy. 2017;31(12):5327-5341. https://doi.org/10.1007/s00464-017-5612-z

6. Yang X. Hua R. He K. Shen Q, Yao Q. Laparoscopic hernioplasty of hiatal hernia. Annals of Translational Medicine. 2016;4(18):343. https://doi.org/10.21037/atm.2016.09.03

7. Durleshter V. M., Siyukhov R. Sh., Uvarov I. B., Svechkar I. Yu., Beretar R. B. [et al.] Method of plastic of the oesopheal holes of the iris. Patent RU 2525732; 20.08.2014. Available at: http://www.freepatent.ru/patents/2525732

\section{About authors:}

Beretar' Ruslan Batyrbievich, MD, Surgeon; tel.: +79184776687; e-mail: dr.beretar@mail.ru

Siyukhov Ruslan Shumafovich, CMSc, Assistant of Professor of the Department of surgery № 3, Surgeon; tel.: +79284177828; e-mail: siuhov@mail.ru

Durleshter Vladimir Moiseevich, DMSc, Professor, Head of the Department of surgery № 3, Deputy Chief Physician for Surgery; tel.: +79882477866; e-mail: durleshter59@mail.ru

Svechkar' Igor Yurievich, CMSc, Surgeon; tel.: +79284119057; e-mail: svechkar84@mail.ru

Bykov Mikhail Ilyich, DMSc, Associate Professor of the Department of surgery № 1 , Head of the Department of endoscopy № 2; e-mail: ilya.bh@mail.ru 